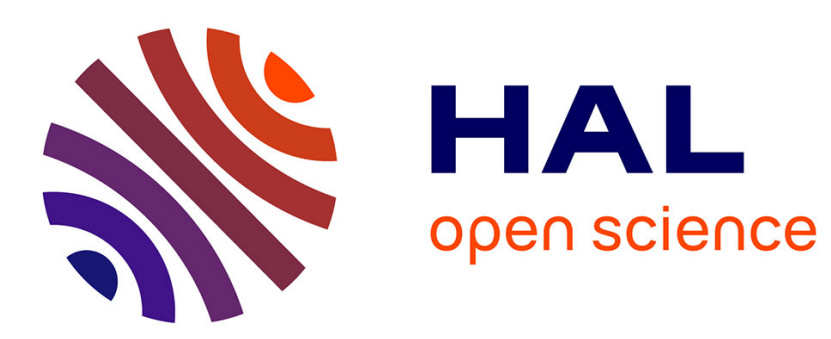

\title{
"Lexicographers of all countries, unite!" About the common semester of the European Master in Lexicography (EMLex) in Nancy
}

\author{
Eva Buchi, Wiebke Blanck
}

\section{- To cite this version:}

Eva Buchi, Wiebke Blanck. "Lexicographers of all countries, unite!" About the common semester of the European Master in Lexicography (EMLex) in Nancy. Lexicographica. International Annual for Lexicography, 2018, 34, pp.367-372. halshs-02109606

\section{HAL Id: halshs-02109606 \\ https://shs.hal.science/halshs-02109606}

Submitted on 25 Apr 2019

HAL is a multi-disciplinary open access archive for the deposit and dissemination of scientific research documents, whether they are published or not. The documents may come from teaching and research institutions in France or abroad, or from public or private research centers.
L'archive ouverte pluridisciplinaire HAL, est destinée au dépôt et à la diffusion de documents scientifiques de niveau recherche, publiés ou non, émanant des établissements d'enseignement et de recherche français ou étrangers, des laboratoires publics ou privés. 


\section{"Lexicographers of all countries, unite!" About the common semester of the European Master in Lexicography (EMLex) in Nancy}

\section{Éva Buchi (ATILF, CNRS/Université de Lorraine)/}

\section{Wiebke Blanck (Friedrich-Alexander-Universität Erlangen-Nürnberg)}

From 26 February to 15 June 2018, the Université de Lorraine (Nancy, France) hosted the common second semester of the "Igor Mel'čuk" class (2017-2019) of the European Master in Lexicography (EMLex), an Erasmus Mundus Joint Master's Degree funded by the European Union and delivered jointly by eight universities: Friedrich-Alexander-Universität ErlangenNürnberg (Erlangen, Germany), Károli Gáspár Református Egyetem (Budapest, Hungary), Università degli Studi Roma Tre (Italy), Stellenbosch University (South Africa), Université de Lorraine, Universidade do Minho (Braga, Portugal), Uniwersytet Śląski w Katowicach (Katowice, Poland) and Universidade de Santiago de Compostela (Spain).

The "Igor Mel'čuk" class, whose students are currently completing the second year of their EMLex studies at their home universities, comprises 22 students, 19 of which are Erasmus Mundus scholars: two Brazilians (Ângela Zanelato Contier and Marina de Melo Soares dos Santos), two Chinese (Jianan Shao and Mingming Zhao), two Frenchwomen (Camille Muller and Manon Perin), one German (Malina Patel), one Indian (Saee Kulkarni), one Indonesian (Mochamad Wahyu Hidayat), one Italian (Clarissa Stincone), two Ivorians (Konan Jean Mermoz Kouassi and Djeya Ange Océane Meyan), one Kazakh (Gulzhazira Yesmakhanova), one Mexican (Laura Hernández Guadarrama), one Polish woman (Sonia Kropiowska), one Russian (Anastasia Okolnikova), two Serbs (Marija Žarković and Nikola Zdravković), one Spaniard (Nerea López Iglesias), and three Ukrainians (Yuliia Bolbit, Sofiia Bychkovska, and Elena Khomyakova).

Nikolay Chepurnykh from the "Samuel Linde" class (2016-2018) acted as "EMLex Student Manager". In this capacity, he gave support to the students of the "Igor Mel'čuk" class during their entire stay in Nancy and documented highlights from their semester on the EMLex Facebook page (https://www.facebook.com/emlex.master).

During the integration week (26 February - 3 March), the students attended information meetings and French language classes on campus, enjoyed cultural events (a sightseeing tour and a Berlioz concert), and also social activities (a French cooking night, organised by Camille Muller and Manon Perin, a French pastry workshop, an excursion to Metz and Amnéville). Under the guidance of Laurent Gobert (ATILF, CNRS/Université de Lorraine), they even invented a new sport aptly named dicogym, a very enjoyable activity involving gymnastics with dictionary volumes.

Nine successive courses made up the major part of the semester:

- Metalexicography (Rufus H. Gouws, Stellenbosch University/Zita Hollós, Károli Gáspár Református Egyetem);

- History of lexicography (Paolo Vaciago, Università degli Studi Roma Tre/Anja LobensteinReichmann, Frühneuhochdeutsches Wörterbuch/Akademie der Wissenschaften zu Göttingen);

- Learner's dictionaries (Michael Klotz, Friedrich-Alexander-Universität ErlangenNürnberg/Stefania Nuccorini, Università degli Studi Roma Tre); 
- Using dictionaries (Martina Nied Curcio, Università degli Studi Roma Tre/Sascha Wolfer, IDS Mannheim);

- Specialised lexicography (Idalete Maria da Silva Dias, Universidade do Minho/Stefan Schierholz, Friedrich-Alexander-Universität Erlangen-Nürnberg);

- Computational lexicography (Stefan Evert, Friedrich-Alexander-Universität ErlangenNürnberg/Ulrich Heid, Universität Hildesheim);

- Dictionaries and translation (María José Domínguez Vázquez, Universidade de Santiago de Compostela/Ewa Myrczek-Kadłubicka, Uniwersytet Śląski w Katowicach);

- Lexicography and lexicology (Éva Buchi, Université de Lorraine/Carlos Valcárcel Riveiro, Universidade de Vigo);

- Dictionary planning (Annette Klosa, IDS Mannheim).

In parallel, the EMLex consortium organised 29 open lectures at the Université de Lorraine:

- Maxime Amblard (Loria/Université de Lorraine): "Formal modelling of dialogue: how words interact (not only in the dictionary!)";

- Henri Béjoint (CRTT/Université Lumière-Lyon-II): "Dictionaries and societies in Britain and the USA";

- Alex Boulton (ATILF/Université de Lorraine): "Reference tools for language learners: dictionaries, corpora, web";

- Frédérique Brin-Henry (ATILF/Centre Hospitalier de Bar-le-Duc): "Terminology/terminography and speech therapy: what kind of research for what kind of applications?";

- Éva Buchi (ATILF/CNRS) and Carlos Valcárcel Riveiro (Universidade de Vigo): "Why and how synchronic and diachronic lexicology and lexicography meet";

- Mathieu Constant (ATILF/Université de Lorraine): “A taste of Natural language processing (NLP): on the use of lexicon";

- María José Domínguez Vázquez (Universidade de Santiago de Compostela): "Zur Typologie der elektronischen Wörterbücher und Portale. Die Begriffe multilingual und plurilingual im Fokus";

- Steven N. Dworkin (University of Michigan): "The content and structure of entries in etymological and historical dictionaries";

- Stefan H. Engelberg (IDS Mannheim): "Lexicography of language contact: the German Loanword Portal";

- Stefan Evert (Friedrich-Alexander-Universität Erlangen-Nürnberg): “(Association) measure for measure: evaluating the corpus-based identification of lexical collocations";

- Bertrand Gaiffe (ATILF/CNRS): "The Text Encoding Initiative (TEI) as a tool for lexicographers";

- Rufus H. Gouws (Stellenbosch University): "Lexicography - from the clay tablet to the internet";

- Yan Greub (ATILF/CNRS): "Recent developments in the Französisches Etymologisches Wörterbuch (FEW)";

- Patrick Hanks (University of the West of England/University of Wolverhampton): "Usage patterns and meaning";

- Ulrich Heid (Universität Hildesheim): "Term candidate extraction and relation extraction with standard corpus linguistic tools";

- Zita Hollós (Károli Gáspár Református Egyetem): "Prototyp eines zweisprachigen Internetwörterbuchs für Deutsch als Fremdsprache";

- Annette Klosa (IDS Mannheim): “Web design for online dictionaries"; 
- Michael Klotz (Friedrich-Alexander-Universität Erlangen-Nürnberg): "Have corpora improved English learner's dictionaries?";

- Anja Kotsch-Smith (ATILF/Université de Lorraine): "'Stereotype Sprechakte' auf Deutsch und Französisch: Fragen zur Erstellung eines phraseologischen Wörterbuchs online";

- Sarah Kremer (Atelier National de Recherches Typographiques/ATILF): "Some typographic tools for an etymological dictionary";

- Igor Mel'čuk (Observatoire de linguistique Sens-Texte/Université de Montréal): "Explanatory Combinatorial Dictionaries: a practical introduction";

- Martina Nied Curcio (Università degli Studi Roma Tre) and Sascha Wolfer (IDS Mannheim): "Search strategies and user behavior in online language resources. An observation study with learners of German";

- Stefania Nuccorini (Università degli Studi Roma Tre): “'Napoleon had a beautiful white hand': phraseology in a nineteenth-century English-French dictionary";

- Denis Paperno (Loria/CNRS): "Introduction to distributional semantics: something to glean for the lexicographer?";

- Alain Polguère (ATILF/Université de Lorraine): "The geometry of lexical models";

- Stefan Schierholz (Friedrich-Alexander-Universität Erlangen-Nürnberg): "Die Zukunft des Wörterbuchs";

- Sven Tarp (Aarhus Universitet): "Goodbye to dictionaries";

- Sabine Tittel (Dictionnaire Étymologique de I'Ancien Français/Heidelberger Akademie der Wissenschaften): "People, paper, online, ongoing: the Dictionnaire Étymologique de l'Ancien Français (DEAF) and its place in eLexicography";

- Elizaveta Zimont (Université de Liège/FNRS): "Adjectives and adverbs in the Dutch-French lexicography (1527-1700): between conventionality and reality".

One of the most important events for our students certainly was the EMLex Master's colloquium, which was held on 13 April, with ten students from the "Samuel Linde" class presenting their Master's dissertations:

- Chris Catacata (Universidade do Minho): "Modalpartikeln in deutschen Lernerwörterbüchern" (supervisor: Idalete Maria da Silva Dias; foreign expert: Martina Nied Curcio, Università degli Studi Roma Tre);

- Nikolay Chepurnykh (Université de Lorraine): "Vers une hiérarchie d'étiquettes sémantiques pour la langue russe: approche lexicographique" (supervisor: Alain Polguère; foreign expert: Carlos Valcárcel Riveiro, Universidade de Vigo);

- Polina Goriunova (Università degli Studi Roma Tre): "A travel dictionary for Russian tourists" (supervisor: Martina Nied Curcio; foreign expert: Idalete Maria da Silva Dias, Universidade do Minho);

- Tomara Gotkova (Université de Lorraine): “A core environmental Russian terminology and its connection to the general language" (supervisor: Alain Polguère; foreign expert: MarieClaude L'Homme, Université de Montréal);

- Žanete Hegmane (Université de Lorraine): "Copyright terminology in the Inter-Active Terminology for Europe (IATE): meeting translators' needs" (supervisor: Yvon Keromnes; foreign expert: Ewa Myrczek-Kadłubicka, Uniwersytet Śląski w Katowicach);

- Jia Hwee Lau (Università degli Studi Roma Tre): "Travel dictionaries for German tourists" (supervisor: Martina Nied Curcio; foreign expert: Sascha Wolfer, IDS Mannheim);

- Polina Mikhel (Université de Lorraine): "Collocational lexical units in Russian" (supervisor: Alain Polguère; foreign expert: Carlos Valcárcel Riveiro, Universidade de Vigo); 
- Olha Novikova (Universidade de Santiago de Compostela): "Lexicographic resources in machine translation. Challenges and perspectives" (supervisor: Pablo Gamallo Otero; foreign expert: Idalete Maria da Silva Dias, Universidade do Minho);

- Nikolett Rus (Károli Gáspár Református Egyetem): “Lexikographische Makrostrukturen: mögliche thematische Anordnungsformen des deutschen Wortschatzes in allgemeinen und Lernerwörterbüchern mit einem spezifischen Anwendungsaspekt" (supervisor: Zita Hollós; foreign expert: Monika Bielińska, Uniwersytet Śląski w Katowicach);

- Jin Jing Teo (Università degli Studi Roma Tre): "Travel dictionary: Chinese-speaking tourists in Rome, Italy" (supervisor: Martina Nied Curcio; foreign expert: Sascha Wolfer, IDS Mannheim).

The students of the "Samuel Linde" and the "Igor Mel'čuk" classes participated in lively discussions about the various Master's dissertations, and many students of the "Igor Mel'čuk" class got inspired by these debates for their own dissertations.

On 14 April, students and teachers went for an excursion to lake Madine in the Lorraine countryside. Tomara Gotkova had organised for two EMLex teams to participate in the Nancy Ekiden relay race on 15 April: they formed the "Blue team" (Polina Goriunova, Žanete Hegmane, Sonia Kropiowska, Saee Kulkarni, Djeya Ange Océane Meyan, and Olha Novikova), and the "White team" (Ângela Zanelato Contier, Laura Hernández Guadarrama, Konan Jean Mermoz Kouassi, Malina Patel, Clarissa Stincone, and Gulzhazira Yesmakhanova). Thus, EMLex made it to the sports section of the local newspaper L'Est Républicain twice (11 April and 16 April).

Furthermore, the four students of the "Samuel Linde" class from the Université de Lorraine Nikolay Chepurnykh, Tomara Gotkova, Žanete Hegmane, and Polina Mikhel - shot a video about their lexicographic experience in their third semester: "Romance etymology, comparative reconstruction, and lexicography: the compilation of a Dictionnaire Étymologique Roman (DÉRom) entry", which is available at the ATILF's web site: http://www.atilf.fr/DERom.

The common semester was then concluded by two intense days. On 14 June, the EMLex Career Day took place under the patronage of the Universite de Lorraine's Orientation and Professional Integration Services (SDOIP), involving two highlights: a round table with lexicographers from publishing houses established in seven countries (Ch. Beck, Duden, Editorial SM, Pharos Dictionaries, Porto Editora, Reverso-Softissimo, and Zanichelli) and 90 minutes of "speed advising", during which about thirty EMLex students and recent graduates benefited from practical advice provided by representatives from the above-named companies that specialise in dictionary publication, as well as from recruitment consultants and academics.

On the morning of 15 June, the four students of the "Samuel Linde" class from the Université de Lorraine had their dissertation vivas before an international examination board. After their successful examination, the graduation ceremony took place in the afternoon, in presence of the Presidents and Vice-Presidents of the EMLex universities and of the company representatives who had taken part in the EMLex Career Day. One of the highlights of this ceremony was the EMLex song composed by Carlos Valcárcel Riveiro and intoned by students, teachers, Presidents, and company representatives alike. The festivities culminated in an unforgettable EMLex party hosted by Saee Kulkarni, Djeya Ange Océane Meyan, Jianan Shao, Gulzhazira Yesmakhanova, and Mingming Zhao at a restaurant in the countryside near 
Nancy. The students are now leaving for internships and will return to their EMLex home universities in early autumn to commence their second year in the programme, which will conclude with their own Master's dissertation.

Shortly after the end of this enjoyable and successful summer term, the EU informed the coordinating institution of the EMLex that the application for another Erasmus Mundus funding had been granted, with the funding period starting in September 2018. The EMLex will thus remain an Erasmus Mundus Master until 2024. 